\title{
Radiasi Eksternal Karsinoma Nasofaring sebagai Penyebab Gangguan Dengar Sensorineural
}

\author{
Rakhmat Haryanto, Ongka M. Saefuddin, Thaufiq S. Boesoirie \\ Bagian Ilmu Kesehatan Telinga, Hidung, Tenggorok, Bedah Kepala dan Leher \\ Fakultas Kedokteran Universitas Padjadjaran \\ Rumah Sakit Hasan Sadikin, Bandung
}

\begin{abstract}
Abstrak
Radiasi berperan penting pada pengobatan kanker kepala leher karena reseksi bedah sering tidak memungkinkan, tetapi menimbulkan efek samping gangguan dengar sensorineural. Penelitian observasional rancangan longitudinal ini untuk mengetahui pengaruh radiasi terhadap gangguan dengar sensorineural penderita karsinoma nasofaring di Bagian THT-KL Rumah Sakit Hasan Sadikin Bandung periode Februari-Agustus 2006. Didapatkan 28 laki-laki dan 7 perempuan, yang satu atau kedua telinganya tidak terganggu pendengaran sensorineural, usia 12-72 tahun, dan memenuhi kriteria inklusi. Seluruh penderita mendapat radiasi dan pemeriksaan audiometri serta timpanometri sebelum, durante $2.000 \mathrm{cGy}, 6.600 \mathrm{cGy}$, dan satu bulan pascaradiasi. Data dianalisis secara statistik menggunakan uji Chi-kuadrat, Mc-Nemar, dan eksak Fisher. Hasil penelitian menunjukkan kejadian gangguan dengar sensorineural durante 2.000 cGy adalah 7 kasus (10\%), 6.600 cGy 22 kasus (31,4\%), dan pascaradiasi 24 kasus $(34,3 \%)$. Hubungan antara durante $6.600 \mathrm{cGy}$ dan $2.000 \mathrm{cGy}$ pada kelompok preradiasi normal sangat bermakna $(\mathrm{p}=$ $0,001)$, sedangkan antara pascaradiasi dan durante 6.600 cGy tidak bermakna $(p=0,5)$. Pada usia $>30$ tahun gangguan dengar sensorineural 37,0\% durante $6.600 \mathrm{cGy}(\mathrm{p}=0,031)$ dan 40,7\% pascaradiasi ( $\mathrm{p}=0,018)$. Simpulan, radiasi karsinoma nasofaring dapat menyebabkan gangguan dengar sensorineural selama dan pascaradiasi, serta usia >30 tahun merupakan faktor prognosis gangguan dengar sensorineural. [MKB. 2010;42(3):108-14].
\end{abstract}

Kata kunci: Gangguan dengar sensorineural, karsinoma nasofaring, radiasi

\section{Nasopharyngeal Carcinoma External Radiation As Causal of Sensorineural Hearing Loss}

\begin{abstract}
Radiation has an important role on nasopharyngeal carcinoma therapy because surgery is often difficult, however it cause sensorineural hearing loss as side effect. Longitudinal observational study was conducted to know the effect of radiation on sensorineural hearing loss of nasopharyngeal carcinoma patients at Ear, Nose, and Throat Department, Hasan Sadikin Hospital, February-August 2006. Twenty eight male and 7 female, with no sensorineural hearing loss in one or both ears, age 12-72 years, and met inclusion criteria, were included in this study. All patients received radiation and underwent audiometry and tympanometry prior-,during-radiation with a $2.000 \mathrm{cGy}$ and 6,600 cGy, and one month postradiation. Data was analyzed using Chi-square, Mc-Nemar, and exact Fisher test. The results showed that incidence of sensorineural hearing loss were 7 cases (10\%) on 2,000 cGy, 22 cases $(31.4 \%)$ on 6,600 cGy, and 24 cases $(34.3 \%)$ on postradiation. The relationship between duration 6,600 cGy and 2,000 cGy in the normal preradiation group were significant $(\mathrm{p}=0.001)$, whereas postradiation and duration with 6,600 cGy was not significant $(p=0.5)$. Sensorineural hearing loss on $>30$ years was $37.0 \%$ on duration $6,600 \mathrm{cGy}(\mathrm{p}=0.031)$ and $40.7 \%$ postradiation $(\mathrm{p}=0.018)$. In conclusion, radiation on nasopharyngeal carcinoma can induce sensorineural hearing loss during- or postradiation and age $>30$ years is prognostic factor for sensorineural hearing loss.
\end{abstract}

[MKB. 2010;42(3):108-14].

Key words: Nasopharyngeal carcinoma, radiation, sensorineural hearing loss

Korespondensi: dr. Rakhmat Haryanto, Bagian Ilmu Kesehatan Telinga Hidung Tenggorok Bedah Kepala Leher Fakultas Kedokteran Universitas Padjadjaran, Rumah Sakit Hasan Sadikin Bandung, jalan Pasirkaliki 190 Bandung 40161, telepon (022) 2034472, Fax. (022) 2040984 


\section{Pendahuluan}

Angka kejadian karsinoma nasofaring (KNF) $\pm 85-95 \%$ dari seluruh keganasan nasofaring dan merupakan tumor ganas yang tersering ditemukan di bidang telinga hidung tenggorok bedah kepala dan leher (THT-KL). Insidensi KNF di dunia bervariasi tergantung keadaan geografis setempat dan diperkirakan $1 / 100.000$ penduduk per tahun. ${ }^{1}$

Survei Departemen Kesehatan RI pada tahun 1997-1999, insidesi di Indonesia 4,7 kasus per 100.000 penduduk per tahun (research center). Dari hasil penelitian di subbagian Tumor THT FK Universitas Indonesia/Rumah Sakit Dr. Cipto Mangunkusumo tahun 1995-2001 ditemukan 620 kasus KNF dengan rasio laki-laki lebih banyak dari perempuan. ${ }^{2}$ Di RSUP Dr Kariadi Semarang tahun 1992-1998, KNF menempati urutan yang pertama dengan angka kejadian $59,52 \%$ dari seluruh keganasan kepala dan leher. ${ }^{3}$ Di Rumah Sakit Hasan Sadikin Bandung dalam periode 1999-2004 terdapat 449 kasus KNF yang datang berobat ke Bagian THT-KL FK Universitas Padjadjaran Rumah Sakit Hasan Sadikin. ${ }^{4}$

Di antara keganasan pada kepala leher, KNF mempunyai prognosis yang paling buruk karena letaknya sangat dekat dengan dasar tengkorak dan struktur vital lainnya serta bersifat invasif. Diagnosis dini sering sulit ditegakkan karena gejala awal tidak jelas dan kesulitan pemeriksaan nasofaring. ${ }^{1,5}$ Kelainan dan keluhan justru timbul akibat penjalarannya ke kelenjar limfe leher dan gangguan saraf otak sehingga penderita datang pada stadium lanjut yang menyebabkan tingginya angka kematian. ${ }^{6,7}$

Penatalaksanaan KNF berupa radiasi, kemoterapi, pembedahan, atau kombinasinya. ${ }^{1}$

Terapi radiasi memegang peranan penting dalam pengobatan kanker kepala leher, karena KNF dekat dengan basis tengkorak sehingga tindakan reseksi bedah dengan tepi bebas tumor tidak memungkinkan. ${ }^{8,9}$ Terapi kuratif diberikan untuk stadium dini dan lanjut lokal, sedang untuk stadium lanjut diberikan terapi paliatif. ${ }^{8}$ Untuk radiasi digunakan sinar gama ${ }^{60} \mathrm{Co}$ atau $4-6 \mathrm{MeV}$ foton untuk terapi lapangan yang luas. Skema terapi yang paling umum adalah pemberian 4.500 cGy dengan dosis harian 180-200 cGy dari arah samping yang mengenai nasofaring serta leher sebelah kanan dan kiri. Leher bagian bawah sering diradiasi dari arah anterior untuk melindungi laring dan medula spinalis, maka tulang temporal dan struktur di dalamnya termasuk sasaran. ${ }^{9}$

Walaupun radiasi memberikan kesembuhan, tetapi dapat juga menimbulkan komplikasi akut maupun kronik. Waktu yang diperlukan untuk terjadinya komplikasi akut tergantung siklus sel dan reaksi mukosa yang terjadi pada minggu kedua. Efek radiasi akut terhadap jaringan normal biasanya berkurang dalam beberapa minggu pascaterapi dan tidak merupakan masalah besar. Menurut the Radiation Therapy Oncology Group (RTOG) efek radiasi akut biasanya mencapai puncak dalam 90 hari. Umumnya penyembuhan permukaan epitel terjadi dalam waktu 20-40 hari pascaterapi, mempergunakan kombinasi radiasi dan kemoterapi agresif, efek akutnya $>90$ hari. ${ }^{10,11}$

Perlu diperhatikan pengaruh radiasi apabila dipergunakan jangka panjang karena kerusakan jaringan dapat bersifat permanen. Sebagian besar efek radiasi jangka panjang terjadi dalam tiga tahun pertama pengobatan dan sebagian kecil setelah tiga tahun. Komplikasi radiasi lambat atau jangka panjang antara lain serostomia, kerusakan gigi, fibrosis, nekrosis jaringan lunak, nekrosis kartilago, kerusakan mata, telinga, dan susunan saraf pusat (SSP). ${ }^{11}$

Terdapat beberapa strategi terapi modern yang dikembangkan untuk meminimalkan komplikasi radiasi pada organ/struktur penting seperti korda spinalis, otak, kiasma optikus, kelenjar pituitari, dan mata. Rekomendasi perlindungan koklea dan saraf auditorius belum banyak dilaporkan. Organ penting telinga dalam tidak dapat dielakkan termasuk dalam daerah radiasi, khususnya terapi pasien KNF. ${ }^{12}$ Beberapa peneliti melaporkan telah terjadi gangguan dengar sensorineural dengan variasi antara $0-50 \%$, meskipun masih ada yang meragukan insidensi, waktu timbul, tipe, dan beratnya gangguan dengar. Sejumlah artikel dan penelitian membahas masalah mengenai terapi radiasi pada pasien KNF dengan komplikasi otitis media eksterna (OME) yang dihubungkan dengan disfungsi tuba eustachius. Bahaya potensial akibat radiasi berupa gangguan perkembangan dengar sensorineural masih sangat sedikit diteliti. ${ }^{12}$

Tujuan penelitian ini untuk mengetahui efek radiasi eksternal KNF terhadap gangguan dengar sensorineural.

\section{Metode}

Penelitian dilakukan secara analitik observasional 
dengan rancangan longitudinal untuk mengetahui efek radiasi eksternal pada karsinoma nasofaring terhadap gangguan dengar sensorineural. Subjek diikutsertakan berdasarkan urutan kedatangan (consecutive sampling from admission), periode Februari-Agustus 2006.

Subjek penelitian terdiri dari 35 penderita KNF yang akan menjalani radiasi eksternal yang memenuhi kriteria inklusi dan tidak memenuhi kriteria eksklusi. Kriteria inklusi adalah semua penderita yang didiagnosis karsinoma nasofaring dan diputuskan hanya mendapat terapi radiasi eksternal. Kriteria eksklusi adalah penderita dengan penyakit telinga kronik selain OME yang ada kaitannya dengan KNF, gangguan dengar sensorineural/campuran sebelum terapi radiasi, pernah mendapatkan terapi radiasi, dan terdapat invasi tumor ke telinga tengah atau dalam.

Pemeriksaan timpanometri dan audiometri nada murni dilakukan di poli subbagian Audiologi THT-KL sebelum, durante $2.000 \mathrm{cGy}$, dan 6.600 cGy, serta satu bulan pascaradiasi.

Besarnya angka kejadian gangguan dengar sensorineural terhadap literatur (7,7\%) digunakan uji Z, sedangkan untuk menentukan hubungan karakteristik penderita dengan kejadian gangguan dengar sensorineural digunakan uji kai kuadrat, Mc-Nemar, dan Eksak Fisher.

\section{Hasil}

Karakteristik subjek penelitian terdiri dari 28 laki- laki $(80 \%)$ dan tujuh perempuan $(20 \%)$, dengan rasio $4: 1$. Usia subjek antara 12 sampai 72 tahun dengan usia rata-rata 40 tahun, terbanyak pada kelompok usia 30-39 tahun dan lebih dari 50 tahun, masing-masing sebanyak 10 orang $(28,6 \%)$. Stadium tumor KNF yang paling banyak ditemukan adalah stadium IV sebanyak 20 kasus $(57,1 \%)$, diikuti stadium III sebanyak delapan kasus $(22,9 \%)$ dan stadium II tujuh kasus $(20 \%)$. Gambaran histopatologi sebagian besar adalah undifferentiated carcinoma sebanyak 31 kasus (88,6\%), sedangkan squamous cell carcinoma empat kasus $(11,4 \%)$.

Hasil pemeriksaan audiometri durante 2.000 cGy dan $6.600 \mathrm{cGy}$, serta pascaradiasi kelompok conductive hearing loss (CHL) digabungkan dengan kelompok audiogram normal yang disebut kelompok ambang hantaran tulang normal (HTNm), dan sensorineural hearing loss (SNHL) disebut kelompok ambang hantaran tulang naik (HTNk).

Pada Tabel 1 terlihat hasil audiometri dengan radiasi 2.000 cGy (10 fraksi) didapatkan SNHL sebanyak tujuh kasuh (10,0\%), setelah menjalani radiasi $6.600 \mathrm{cGy}$ meningkat menjadi 22 kasus (31,4\%). Peningkatan kasus SNHL juga terjadi pada satu bulan pascaradiasi menjadi 24 kasus $(34,3 \%)$.

Hubungan hasil pemeriksaan audiogram durante $2.000 \mathrm{cGy}$ dengan $6.600 \mathrm{cGy}$ dan durante $6.600 \mathrm{cGy}$ dengan pascaradiasi ditunjukkan pada Tabel 2,3,4, dan 5 .

Tabel 2 menunjukkan bahwa radiasi durante

Tabel 1 Hasil Audiometri pada Penderita Karsinoma Nasofaring Sebelum dan Sesudah Menjalani Radioterapi

\begin{tabular}{lcc}
\hline Hasil Pemeriksaan Audiometri & Jumlah & \% \\
\hline Preradiasi & & \\
Normal & 51 & 72,9 \\
CHL & 19 & 27,1 \\
Radiasi Durante 2.000 cGy & & 62,9 \\
Normal & 44 & 27,1 \\
CHL & 19 & 10,0 \\
SNHL & 7 & 44.3 \\
Radiasi Durante 6.600 cGy & 31 & 24,3 \\
Normal & 17 & 31,4 \\
CHL & 22 & 45,7 \\
SNHL & & 20.0 \\
Pascaradiasi & 32 & 34,3 \\
Normal & 14 & \\
CHL & 24 & \\
SNHL & & \\
CHL:
\end{tabular}

Keterangan: CHL: conductive hearing loss; SNHL: sensorineural hearing loss 
Rakhmat Haryanto: Radiasi Eksternal Karsinoma Nasofaring sebagai Penyebab Gangguan Dengar Sensorineural

Tabel 2 Hubungan antara Hasil Audiometri Durante 6.600 cGy dan 2.000 cGy pada Kelompok Preradiasi Normal

\begin{tabular}{|c|c|c|c|}
\hline \multirow{2}{*}{ Audiom etri Durante Radiasi } & \multicolumn{2}{|c|}{ Durante 6.600 cGy } & \multirow[b]{2}{*}{$\mathbf{p}$} \\
\hline & HTNm & HTNk & \\
\hline \multicolumn{4}{|l|}{ Durante 2.000 cGy } \\
\hline HTNm & $36(76,6 \%)$ & $11(23,4 \%)$ & 0,125 \\
\hline HTNk & 0 & $4(100,0 \%)$ & \\
\hline
\end{tabular}

Tabel 3 Hubungan antara Hasil Audiometri Durante 6.600 cGy dan 2.000 cGy pada Kelompok Preradiasi CHL

\begin{tabular}{lccc}
\hline \multirow{2}{*}{ Audiom etri Durante Radiasi } & \multicolumn{2}{c}{ Durante 6.600 cGy } & \multirow{2}{*}{ p } \\
\cline { 2 - 3 } Durante 2.000 cGy & HTNm & HTNk & \\
HTNm & $12(75 \%)$ & $4(25,0 \%)$ & \\
HTNk & 0 & $3(100,0 \%)$ & 0,125 \\
\hline
\end{tabular}

Keterangan: Nilai p dihitung berdasarkan uji Mc-Nemar; HTNm: hantaran tulang normal; HTNk: hantaran tulang naik

Tabel 4 Hubungan antara Hasil Audiometri Pascaradiasi dengan Durante 6.600 cGy pada Kelompok preradiasi Normal

\begin{tabular}{lccc}
\hline \multirow{2}{*}{ Audiom etri Durante Radiasi } & \multicolumn{2}{c}{ Pascaradiasi } & \multirow{2}{*}{ p } \\
\cline { 2 - 4 } Durante 6.600 cGy & HTNm & HTNk & \multirow{2}{*}{0,5} \\
HTN m & $34(94,4 \%)$ & $2 \quad(5,6 \%)$ & \\
HTNk & 0 & $15(100,0 \%)$ & \\
\hline
\end{tabular}

Keterangan: Nilai p dihitung berdasarkan uji Mc-Nemar; HTNm: hantaran tulang normal; HTNk: hantaran tulang naik

Tabel 5 Hubungan antara Hasil Audiometri Pascaradiasi dengan Durante 6.600 cGy pada Kelompok preradiasi CHL

\begin{tabular}{lccc}
\hline \multirow{2}{*}{ Audiom etri Du rante Radiasi } & \multicolumn{2}{c}{ Pascaradiasi } & PTNk \\
\cline { 2 - 3 } Durante 6.600 cGy & HTNm & & 1,0 \\
HTNm & $12(100 \%)$ & 0 & \\
HTNk & 0 & $7(100,0 \%)$ & \\
\hline Keterangan: Nilai p dihitung berdasarkan uji Mc-Nemar; HTNm: hantaran tulang normal; HTNk: hantaran tulang naik
\end{tabular}

$6.600 \mathrm{cGy}$ pada kelompok preradiasi normal telah terjadi kenaikan kasus HTNk sebesar 11 kasus $(23,4 \%)$ yang berasal dari audiogram HTNm durante 2.000 cGy yang sebelumnya sudah ada empat kasus. Secara statistik sangat bermakna hubungan antara durante 6.600 cGy dan 2.000 cGy pada kelompok audiometri preradiasi normal $(p=0,001)$. Tabel 3 menunjukkan kelompok audiometri preradiasi CHL terjadi juga kenaikan kasus HTNk sebesar empat kasus (25\%) yang berasal dari audiogram HTNm durante $2.000 \mathrm{cGy}$ yang sebelumnya sudah ada tiga kasus, tetapi secara statistik tidak bermakna $(\mathrm{p}=0,125)$.

Pada Tabel 4 dapat dilihat bahwa pascaradiasi pada kelompok preradiasi normal telah terjadi peningkatan dua kasus $\operatorname{HTNk}(5,6 \%)$ yang berasal dari audiogram HTNm dibandingkan dengan durante $6.600 \mathrm{cGy}$ yang sebelumnya sudah ada 15 kasus. Pascaradiasi pada kelompok audiometri preradiasi normal masih terjadi peningkatan kasus HTNk $(p=0,5)$ berasal dari kelompok audiogram normal+CHL dari durante $6.600 \mathrm{cGy}$. Tabel 5 menunjukkan kelompok audiometri preradiasi CHL tidak terdapat peningkatan kasus HTNk, berarti pada kelompok audiometri preradiasi $\mathrm{CHL}$ tidak terjadi kasus baru HTNk.

Angka kejadian HTNk pada laki-laki baik durante 6.600 cGy $(32,7 \%)$ maupun pascaradiasi $(36,4 \%)$ lebih tinggi dibandingkan dengan perempuan (26,7\%), seperti terlihat pada Tabel 6 .

Pada usia $>30$ tahun angka kejadian SNHL sebesar $37,0 \%$ durante 6.600 cGy dan $40,7 \%$ 
Rakhmat Haryanto: Radiasi Eksternal Karsinoma Nasofaring sebagai Penyebab Gangguan Dengar Sensorineural

Tabel 6 Hubungan antara Berbagai Karakteristik dan Pemeriksaan Audiometri

\begin{tabular}{|c|c|c|c|c|c|c|}
\hline \multirow{2}{*}{ Karakteristik } & \multicolumn{3}{|c|}{ Durante $6.600 \mathrm{cGy}$} & \multicolumn{3}{|c|}{ Pascaradiasi } \\
\hline & HTNm & $\overline{\text { HTNk }}$ & $\mathbf{p}$ & HTNm & HTNk & $\mathbf{p}$ \\
\hline \multicolumn{7}{|l|}{ 1. Jenis Kelamin } \\
\hline Laki-laki & $37(67,3 \%)$ & $18(32,7 \%)$ & \multirow{2}{*}{$\mathrm{p}_{\mathrm{EF}}=0,761$} & $35(63,6 \%)$ & $20(36,4 \%)$ & \multirow{2}{*}{$\mathrm{p}_{\mathrm{EF}}=0,483$} \\
\hline Perempuan & $11(73,3 \%)$ & $4(26,7 \%)$ & & $11(73,3 \%)$ & $4(26,7 \%)$ & \\
\hline \multicolumn{7}{|l|}{ 2. Usia } \\
\hline$<30$ tahun & $14(87,5 \%)$ & $2(12,5 \%)$ & \multirow{2}{*}{$\begin{array}{l}X^{2}=3,45 \\
p=0,031\end{array}$} & $14(\mathrm{~S} 7,5 \%)$ & $2(12,5 \%)$ & \multirow{2}{*}{$\begin{array}{l}X^{2}=4,37 \\
p=0,018\end{array}$} \\
\hline$\geq 30$ tahun & $34(33,0 \%)$ & $20(37,0 \%)$ & & $32(59,3 \%)$ & $22(40,7 \%)$ & \\
\hline \multicolumn{7}{|c|}{ 3. Stadium Tumor } \\
\hline II & $12(85,7 \%)$ & $2(14,3 \%)$ & \multirow{3}{*}{$\begin{array}{l}X^{2}=2,59 \\
p=0,273\end{array}$} & $12(85,7 \%)$ & $2(14,3 \%)$ & \multirow{3}{*}{$\begin{array}{l}X^{2}=3,75 \\
p=0,152\end{array}$} \\
\hline III & $11(68,7 \%)$ & $5(31,3 \%)$ & & $11(68,7 \%)$ & $5(31,3 \%)$ & \\
\hline IV & $25(62,5 \%)$ & $15(37,5 \%)$ & & $23(57,5 \%)$ & $17(42,5 \%)$ & \\
\hline \multicolumn{7}{|l|}{ 4. Histopatologi } \\
\hline undiff. ca & $42(67,8 \%)$ & $20(32,3 \%)$ & \multirow{2}{*}{$\mathrm{p}_{\mathrm{EF}}=0,650$} & $40(64,5 \%)$ & $22(35,5 \%)$ & \multirow{2}{*}{$\mathrm{P}_{\mathrm{EF}}=0,005$} \\
\hline SCC & $6(75,0 \%)$ & $2(25,0 \%)$ & & $6(75,0 \%)$ & $2(25,0 \%)$ & \\
\hline
\end{tabular}

Keterangan: $\mathrm{X}^{2}=$ Uji Chi-kuadrat; $\mathrm{p}_{\mathrm{EF}}=$ uji eksak Fisher

pascaradiasi, sedangkan usia $<30$ tahun kejadian SNHL durante 6.600 cGy dan pascaradiasi sebesar $12,5 \%$. Baik pada durante $6.600 \mathrm{cGy}$ maupun pascaradiasi, hubungan usia penderita dengan kejadian SNHL pascaradiasi secara statistik bermakna, seperti yang tertera pada Tabel $6(\mathrm{p}=0,031$ dan $\mathrm{p}=0,018)$.

Durante 6.600 cGy pada tumor stadium IV angka kejadian SNHL lebih tinggi dibandingkan dengan stadium III dan II, tetapi hubungan antara stadium tumor dan angka kejadian SNHL secara statistik tidak bermakna. Hal yang sama juga terjadi pascaradiasi (Tabel 6).

Karsinoma nasofaring tipe undifferentiated carcinoma mempunyai angka kejadian SNHL pascaradiasi lebih tinggi $(32,3 \%$ pada durante 6.600 cGy dan $35,5 \%$ pada pascaradiasi) dibanding tipe squamous cell carcinoma $(25,0 \%$ durante $6.600 \mathrm{cGy}$ dan $25,0 \%$ pascaradiasi), tetapi secara statistik tidak ada perbedaan bermakna $(\mathrm{p}=1,0$ dan $\mathrm{p}=0,706)$.

\section{Pembahasan}

Karakteristik penderita pada penelitian ini tidak jauh berbeda dengan hasil penelitian di subbagian Tumor THT FK UI/RS Dr. Cipto Mangunkusumo dari tahun 1995-2001 terhadap 620 kasus KNF dengan ratio laki-laki lebih banyak dibandingkan dengan perempuan. ${ }^{2}$ Usia penderita sesuai dengan penelitian Djaelani ${ }^{13}$ yang mendapatkan terbanyak pada kelompok usia 50-59 tahun, sedangkan stadium penyakit sesuai dengan penelitian Chen $e t$ al., ${ }^{14}$ terbanyak stadium IV (68\%). Gambaran histopatologis sedikit berbeda dengan hasil penelitian Chen et al. yang mendapatkan tipe undifferentiated carcinoma terbanyak $(73,1 \%)$.

Tabel 1 menunjukkan bahwa dengan dosis 2.000 cGy telah terjadi peningkatan ambang hantaran tulang di atas normal pada tujuh telinga yang merefleksikan telah ada gangguan terhadap kestabilan fungsi koklea atau saraf auditorius. ${ }^{13}$ Kasus SNHL meningkat sejalan dengan peningkatan dosis radiasi (6.600 cGy). Hal ini sesuai dengan penelitian Grou et al. pada tahun 1991 terhadap 22 penderita KNF yang menjalani radiasi eksternal, terdapat hubungan bermakna antara gangguan pendengaran sensorineural dan dosis radiasi yang diterima, seperti dikutip oleh Sataloff. ${ }^{15}$ Gangguan dengar sensorineural pada penelitian ini mulai pada minggu ke-2 radioterapi dan meningkat pada minggu ke-6 dari $10 \%$ menjadi 31,4\%. Menurut The Radiation Therapy Oncology Group (RTOG), efek radiasi terhadap jaringan normal mulai terjadi pada minggu ke-2 dan efek radiasi akut (peak) biasanya terjadi dalam 90 hari dari permulaan terapi radiasi. ${ }^{11} \mathrm{Hal}$ tersebut menunjukkan bahwa selama radiasi telah terjadi obliterasi endarteritis, vaskulitis stria vaskularis temporer, dan degenerasi kolagen otot pembuluh darah yang mengakibatkan kegagalan suplai darah ke koklea, labirin, dan tulang-tulang pendengaran sehingga sudah menimbulkan gangguan fungsi pada organ tersebut. Hasil yang serupa disampaikan oleh Borsanyi dan Blanchard tahun 1962 yang melaporkan studi 14 penderita berbagai jenis kanker daerah kepala dan leher 
yang menerima 4.000-6.000 rad menghubungkan perubahan ambang hantaran tulang pada hasil audiogram sebelum dan sesudah radiasi, seperti dikutip oleh Sataloff. ${ }^{15}$ Hasil penelitian satu bulan pascaradiasi, angka kejadian gangguan dengar sensorineural masih meningkat. Hal ini berarti sebagian penderita (dua kasus) masih mengalami peningkatan ambang dengar sensorineural $(4,16 \%)$. Hal ini sesuai dengan hasil peneltian Wang et $a l^{12}$ bahwa penurunan pendengaran sensorineural setelah pemberian radiasi awalnya kemungkinan bersifat transien, tetapi pengaruh radiasi pada pendengaran cenderung kronik dan progresif. Penelitian Schuknecht dan Karmody berhasil melakukan pemeriksaan histologi penderita pascaradiasi, juga mendapatkan degenerasi stria vaskularis, atropi spiral ligamen, dan membran basilaris. Penelitian Leach yang mendapatkan hilangnya sel rambut luar dan atropi saraf auditorius menyatakan bahwa perubahan patologi di koklea dan saraf auditorius bersifat permanen dan memberikan defek pada fungsi pendengaran sensorineural, seperti dikutip dari Sataloff. ${ }^{15}$

Dari 70 telinga yang pada preradiasi kondisi ambang hantaran tulangnya normal, setelah menerima radiasi $2.000 \mathrm{cGy}$ terdapat tujuh kasus yang menjadi SNHL (10\%) dan meningkat pada radiasi 6.600 cGy menjadi 22 kasus $(31,4 \%)$, serta pascaradiasi 24 kasus (34,3\%). Hasil penelitian ini berbeda dengan penelitian Wang et al. ${ }^{12}$ pada 220 penderita KNF (395 telinga) dengan dosis total radiasi 66-74 Gy mengalami gangguan dengar sensorineural pascaradiasi 7,7\%. Penelitian Leach terhadap 56 penderita karsinoma daerah kepala dan leher yang mendapat radiasi 3000-12.000 rad didapatkan hasil gangguan dengar sensorineural pascaradiasi yang hampir sama, yaitu sebesar $36 \%{ }^{15}$

Hasil audiometri pada kelompok preradiasi normal dan CHL, menunjukkan makin tinggi dosis yang diterima makin meningkat perubahan patofisiologi pada koklea dan saraf auditorius yang menyebabkan peningkatan ambang hantaran tulang penderita. Dosis radiasi berkorelasi secara bermakna dengan hilangnya sel-sel rambut pada organ korti yang direfleksikan dengan adanya peningkatan gangguan dengar sensorineural, yang signifikansinya lebih tinggi pada dosis di atas $5.000 \mathrm{rad}$ dibanding di bawahnya. ${ }^{15,16} \mathrm{Hal}$ ini juga sesuai dengan satu penelitian terhadap tikus yang apabila diasumsikan pada manusia, peningkatan paparan dosis radiasi akan berpengaruh pada degenerasi organ sensoris, sel penunjang, serta serabut saraf auditorius. Telinga yang mengalami paparan dosis radiasi 40-60 cGy, insidensi kerusakan serabut saraf mencapai $31 \%$ dan pada paparan radiasi $60-90 \mathrm{cGy}$ mencapai $62 \%{ }^{17}$

Hasil audiometri kelompok normal dan CHL durante $6.600 \mathrm{cGy}$ menunjukkan masih terjadi perburukan ambang hantaran tulang yang dapat berupa degenerasi stria vaskularis, atropi spiral ligamen, membran basilaris, hilangnya sel rambut luar atau atropi saraf auditorius pascaradiasi satu bulan. ${ }^{12,15}$ Penelitian ini juga sesuai dengan hasil penelitian yang dilakukan oleh Wang et al. ${ }^{12}$ menyatakan bahwa pengaruh radiasi terhadap gangguan dengar sensorineural bersifat transien tetapi cenderung kronik dan progresif.

Tabel 6 menunjukkan kejadian HTNk lebih banyak pada laki-laki $(32,7 \%)$ dibandingkan dengan perempuan $(26,7 \%)$. Hal ini menunjukkan bahwa perempuan dengan KNF yang menjalani radiasi eksternal lebih resisten untuk terjadinya SNHL pascaradiasi meskipun hubungannya secara statistik tidak bermakna. Penelitian ini sesuai penelitian $\mathrm{Oh}$ et al. ${ }^{16}$ yang mendapatkan jenis kelamin sebagai faktor prognosis SNHL pascaradiasi.

Terdapat hubungan antara usia dan kejadian SNHL pascaradiasi. Hal ini sesuai dengan penelitian Oh et al. ${ }^{16}$ bahwa usia merupakan faktor prognosis yang bermakna untuk terjadinya gangguan dengar sensorineural pascaradiasi pada penderita KNF. Hal ini kemungkinan karena perubahan degenerasi yang telah ada pada usia $>30$ tahun membuat lebih mudah terkena trauma radiasi. ${ }^{12,16}$ Angka kejadian SNHL pada berbagai stadium menunjukkan bahwa stadium tumor tidak mempengaruhi atau menjadi faktor prognosis SNHL pascaradiasi.

Menurut gambaran histopatologis, KNF tipe undifferentiated carcinoma merupakan faktor prognosis untuk terjadinya SNHL pascaradiasi dibandingkan dengan tipe SCC meskipun kedua tipe mempunyai sifat radiosensitif. ${ }^{1}$

Disimpulkan bahwa radiasi eksternal pada karsinoma nasofaring menyebabkan gangguan dengar sensorineural baik selama radiasi maupun pascaradiasi. Semakin tinggi dosis radiasi yang diberikan, semakin meningkat gangguan dengar sensorineural, dan tertinggi pascaradiasi. Usia $>30$ tahun merupakan faktor prognosis yang bermakna. 
Disarankan perlu disusun metode pengelolaan gangguan dengar sensorineural pascaradiasi baik untuk pencegahan, terapi, atau rehabilitasi agar tidak terjadi progresivitas dan kerusakan yang permanen. Perlu penjelasan pada penderita yang akan menjalani radiasi karsinoma nasofaring tentang kemungkinan terjadinya gangguan dengar pascaradiasi. Penelitian lebih lanjut diperlukan untuk memastikan efek permanen gangguan dengar sensorineural akibat radiasi karsinoma nasofaring.

\section{Daftar Pustaka}

1. Brian HN III. Benign and malignant neoplasms of the nasopharynx. Dalam: Cumming CW, Frederickson JM, Harker LA, Krause CJ, Schuller DE, penyunting. Otolaryngology-head and neck surgery. Vol. 2. Edisi ke-2. St Louis, Missouri. USA: Mosby Year Book Inc; 1993. hlm. 1361-2.

2. Bagian Patologi Anatomi FKUI. Data histopatologi 1995-2001. Bandung: Bagian PAFKUI; 2010.

3. Muyassaroh, Samsudin, Soetedjo. Kelainan neurologi pada KNF di SMF THT RSUP Dr. Kariadi Semarang tahun 1996-1998. Kumpulan naskah kasus Perhati XII. Semarang, 1999.

4. Bagian THT-KL RS Hasan Sadikin. Laporan tahunan morbiditas pasien rawat jalan 1999-2004. Bandung:Bagian THT-KL; 2010.

5. Lee KJ. Essential otolaryngology, head and neck surgery. Vol. 2. Edisi ke-8. Stamford, Conecticut. USA:Appleton \& Lange; 2003.

6. Schantz SP, Harrison LB, Hong WK. Cancer of the head and neck. Dalam: Devita VT, Samuel H, Steven AR, penyunting. Principle practise radiation of oncology. Edisi ke-5. Philadelphia. USA: Lippincot-Raven Publ; 1997. hlm. 765-71.
7. Susworo R. Kanker nasofaring epidemiologi dan pengobatan mutakhir. Cermin Dunia Kedokteran. 2004;144:18-28.

8. Standar pelayanan profesi radioterapi kanker nasofaring. Jakarta: Perhimpunan Onkologi Radiasi Indonesia; 2002.

9. Perez CA. Nasopharynx. Dalam: Principle and practice of radiation oncology. Edisi ke-3. Philadelphia. USA: Lippincot-Raven; 1998. hlm. 879-935.

10. Mark CW, Bryan HN. Nasopharyngeal cancer. Dalam: Bailey BJ, Calhoun KH, Healy GB, Johnson JT, Jacler RK, Pillsbury III HC, penyunting. Philadelphia USA: Lippincot William \& Wilkins; 2001. hlm. 1413-26.

11. Underbrink M, Pou A. The principle of radiation oncology (diunduh 16 Agustus 2006). Tersedia dari: Http/www.Utmb.Edu/otoref/Grnds/Radia tion-Oncology; 2003-1203. htm.

12. Wang LF. A long-term study on hearing status in patients with nasopharyngeal carcinoma after radiotherapy. J Laryngol Otol. 2004;25:168-73.

13. Djailani. Peranan terapi radiasi terhadap terjadinya otitis media efusi pada penderita karsinoma nasofaring di Bagian THT-KL RS. Hasan Sadikin Bandung (Tesis). Bandung: Program Pascasarjana Combined Degree FK Unpad; 2005.

14. Chen Y, Young YH, Hsu WC. Failure of gromet insertion in post-irradiation otitis media with effusion. An Otol Rhinol Laryngol. 2001;110: 746-8.

15. Sataloff RT. Effect of cranial irradiation on hearing acuity: a review of the literatur. Am J Otol. 1994;15:669-832.

16. Oh YT, Kim CH, Choi JH, Kang SH, Chun M. Sensory neural hearing loss after concurrent cisplatin and radiation therapy for nasopharyngeal carcinoma. J Radiother Oncol 2004;72:79-82.

17. Low WK, Burgess R, Fong WK, Wang DY. Effect of radiotherapy on retro-cochlear auditory 